\title{
Klasszikus és modern vizsgálómódszerek a csontérettségi kor és a pubertáskori növekedési csúcs meghatározására
}

\author{
Frank Dorottya dr. ${ }^{1}$ - Rill Leila dr. ${ }^{1}$ \\ Kolarovszki Béla dr. ${ }^{2}$ - Nagy Ákos Károly dr. ${ }^{3}$ \\ Pécsi Tudományegyetem, Általános Orvostudományi Kar, Klinikai Központ, Fogászati és Szájsebészeti Klinika, \\ ${ }^{1}$ Fogszabályozási Részleg, ${ }^{2}$ Dentoalveolaris Részleg, ${ }^{3}$ Központi Egység, Pécs
}

\begin{abstract}
A szkeletális kormeghatározás mind az antropológia, igazságügyi orvostan, gyermekgyógyászat, endokrinológia, mind pedig a fogszabályozás, állcsont-ortopédia területén kiemelt jelentőséggel bír. A csontkor alapvetően az egyén biológiai fejlettségére ad választ, mely viszonylag tág határok között mozoghat ugyanabban a kronológiai korban. Így a csontérettségnek, illetve a pubertáskori növekedés megítélésének fontos szerepe van bizonyos betegségeknél a diagnózis pontos felállításában, továbbá sok esetben elengedhetetlen a kezelések megfelelő időzítése és sikere szempontjából is. Jelenleg számos módszer áll rendelkezésünkre, melyek segítségével a csontkor, illetve a növekedés üteme meghatározható. A növekedés során a csontok számottevő változáson mennek keresztül, továbbá az egyénben végbemenő változások sorrendje mindig meghatározott. Ezen változások különböző módszerekkel, például radiológiai vizsgálatokkal mérhetők, így a klasszikus módszerek elsősorban a kézcsontok, illetve a nyaki csigolyák morfológiai változásainak radiológiai vizsgálatán alapulnak. Ugyancsak léteznek módszerek, melyek a fogazati fejlettség alapján következtetnek az egyén biológiai érettségére. Azonban a háromdimenziós képalkotó eljárások és a molekuláris diagnosztikai módszerek elterjedésének hála egyre pontosabb vizsgálatokat végezhetünk a biológiai érettség meghatározására. Ezen modern vizsgálómódszerek egyrészrôl a cone-beam komputertomográfos felvételek adatállományából nyert információkon, másrészről pedig a különböző, a keringésben vagy egyéb, testváladékban jelen lévő biomarkerek szintjének mérésén alapulnak. Az összefoglalás célja, hogy áttekintést nyújtson a különböző klasszikus és modern szkeletális kormeghatározást segítő vizsgálómódszerekről, amelyek segítségünkre lehetnek számos tudományterületen.
\end{abstract}

Orv Hetil. 2018; 159(35): 1423-1432.

Kulcsszavak: csontkor, szkeletális érettség, állcsont-ortopédia, pubertáskori növekedés

\section{Classical and modern methods for the assessment of skeletal maturation and pubertal growth spurt}

The assessment of skeletal age is of utmost importance not only in the field of anthropology, forensic medicine, pediatrics, endocrinology but also in orthodontics and jaw orthopedics. Bone age refers to the individual's biological development which can differ within a relatively wide range for the same chronological age. Therefore, accurate assessment of skeletal maturity and pubertal growth plays an important role in establishing a diagnosis for certain diseases. In addition, it is essential for proper timing and success of treatments in many cases. Currently, there are many methods available to determine skeletal age and pubertal growth spurt. During growth, bones undergo significant changes, the sequence of which is strongly determined. These changes can be measured by various methods including radiological examinations. More specifically, these classical methods are often based on the radiological evaluation of morphological changes in the hand bones and cervical vertebrae. Methods based on dental development also exist to assess the biologic maturity of an individual. However, thanks to three-dimensional imaging techniques and molecular diagnostic methods, even more accurate tests can be performed to determine biological maturity. These modern methods rely on the information obtained from the cone-beam computer tomograph records and on the measurements of biomarkers present in different circulatory or other body fluids. The purpose of this summary is to provide an overview of the various classical and modern methods for the assessment of skeletal age that could aid us in many fields of science. 
Keywords: bone age, skeletal maturation, jaw orthopedics, pubertal growth

Frank D, Rill L, Kolarovszki B, Nagy ÁK. [Classical and modern methods for the assessment of skeletal maturation and pubertal growth spurt]. Orv Hetil. 2018; 159(35): 1423-1432.

(Beérkezett: 2018. április 9.; elfogadva: 2018. május 2.)

\begin{abstract}
Rövidítések
@2 = a 2 . nyaki csigolya alsó behúzódásának legmélyebb pontja és a hátulsó alsó csigolyapont, illetve a hátulsó alsó csigolyapont és az elülső alsó csigolyapont által meghatározott egyenesek által bezárt szög; $2 \mathrm{D}=$ kétdimenziós; $3 \mathrm{D}=$ háromdimenziós; $\mathrm{AH} 3 / \mathrm{PH} 3=($ anterior height of $\mathrm{C} 3 /$ posterior height of C3) a 3. nyaki csigolyánál mért elülső csigolyamagasság és a 3 . nyaki csigolyánál mért hátulsó csigolyamagasság aránya; $\mathrm{C} 2-\mathrm{C} 6=\mathrm{a} 2-6$. nyaki csigolya $\mathrm{CBCT}=($ cone-beam computed tomography) cone-beam komputertomográfia; CVMS $=($ cervical vertebral maturation stage $)$ Baccetti-féle csigolyaérettségi stádium; CVS $=($ cervical vertebral stage $)$ Lamparski-féle csigolyaérettségi stádium; $\mathrm{GH}=$ (growth hormone $)$ növekedési hormon; $\mathrm{H} 4 / \mathrm{W} 4=($ height of $\mathrm{C} 4 /$ width of $\mathrm{C} 4)$ a 4. nyaki csigolyánál mért középső csigolyamagasság és a 4. nyaki csigolyánál mért középső csigolyaszélesség aránya; IGFl = (insulin-like growth factor-1) inzulinszerü növekedési faktor-1; IGFBP $=$ (insulin-like growth factor-binding protein $)$ inzulinszerû növekedési faktort kötő fehérje; IGFBP3 = (insulin-like growth factor-binding protein-3) inzulinszerü növekedési faktort kötő fehérje-3; MP3 = (3. metacarpophalangeal) a 3. ujj középső ujjperce; QCVM = (quantitative cervical vertebral maturation) kvantitatív csigolyaérettségi vizsgálómódszer; seIGFl = szérum-IGFl; SMI = (skeletal maturation index $)$ Fishman-féle szkeletális maturációs index; SMIS = Fishmanféle SMI-stádiumok
\end{abstract}

A szkeletális kor különbözik a kronológiai életkortól. Míg a kronológiai kort a születési dátum alapján határozzuk meg, addig a szkeletális kor az egyén biológiai fejlettségének elsődleges indikátora, és viszonylag tág határok között mozoghat ugyanabban a kronológiai korban. Jó néhány egyéb módszer is létezik, mely információt ad az egyén fejlettségi szintjéről - másodlagos nemi jellegek (szexuális érettség), hangváltozás, testmagasságbeli változások -, azonban a szkeletális kormeghatározás a leggyakrabban alkalmazott módszer [1-7]. Számos tudományterület széles körben alkalmazza a szkeletális kormeghatározó módszereket, amelyek antropológusok, igazságügyi orvosszakértők számára nyújtanak szükséges információt. Egyre hangsúlyosabb szerepet kapnak ezek a módszerek a bevándorlási ügyek tekintetében is, mivel a jogi következmények szempontjából az Európába érkező menekültek életkora döntő fontossággal bír. Ennek megállapítása azonban a hiányzó papírok miatt sok esetben lehetetlen, így a hatóságok egyre nagyobb számban igénylik szakértők bevonását [8]. A csontérettség értékelése ugyancsak fontos szerepet játszik a gyermekgyógyászatban, az endokrinológiá- ban nemcsak a diagnózis felállításakor, hanem a kezelés irányításakor is a különböző növekedési és fejlődési zavaroknál. A fogszabályozó kezelések sikere szempontjából ugyancsak kiemelt fontossággal bír [1, 3, 5, 7, 9]. Fogszabályozáskor ugyanis a páciens fejlettsége, növekedési potenciálja alapvetően meghatározza az állcsont-ortopédiai kezelések időzítését és a kezelés eredményességét $[1,10,11]$. Ezen kezelések a pubertáskori növekedés idején a legsikeresebbek, ezért fontos, hogy a diagnózis készítésekor az egyén növekedési üteméról nyert adatokat beépítsük a kezeléstervezésbe.

A szkeletális érettség, csontkor, szkeletális kor, biológiai kor, mivel egymás szinonimái, mind kivétel nélkül arra utalnak, hogy a szervezetben végbemenő csontosodási folyamatok milyen fejlettségi szinten állnak [5]. A növekedés során a csontok számos változáson mennek keresztül, melyek különböző módszerekkel, például radiológiai vizsgálatokkal elemezhetők [3-5]. Az adott egyénben végbemenő változások sorrendje mindig meghatározott, azonban az egyén biológiai órájától függ, hogy a változások mikor történnek meg [5]. Mindezeket kihasználva lehetőségünk van egyrészről új módszereket kifejleszteni, másrészről a már meglévőket használni, melyek segítségével informálódhatunk a szkeletális életkorról, illetve a növekedés üteméról.

Az összefoglalás célja, hogy áttekintést nyújtson a különböző, klasszikus és modern szkeletális kormeghatározást segítő vizsgálómódszerekrôl, melyek segítségünkre lehetnek számos tudományterületen, továbbá alkalmazásukkal - a diagnózisba és kezeléstervezésbe építve - lényegesen növelhetjük például a fogszabályozó és állcsont-ortopédiai kezeléseink sikerességét is.

\section{Klasszikus, szkeletális kort meghatározó vizsgálatok}

\section{A kézcsontok vizsgálatán alapuló módszerek}

A kézcsontok csontosodási folyamatai meghatározott ütemben zajlanak [3], ennek értelmében azok csontosodási sorrendje alkalmas a csontérettségi kor meghatározására. Ezt a megállapítást elsőként 1937-ben Todd igazolta [12], majd ezen megfigyelésekre alapozva az 1950-es évek végén Greulich és Pyle egy általuk publikált atlasszal, melyben nemre és korra jellemző standard kézröntgenfelvételeket sorakoztattak fel, lefektették a szkeletális kormeghatározás alapjait [4]. Megállapításaik a mai napig arany standardnak számítanak. Később Björk 


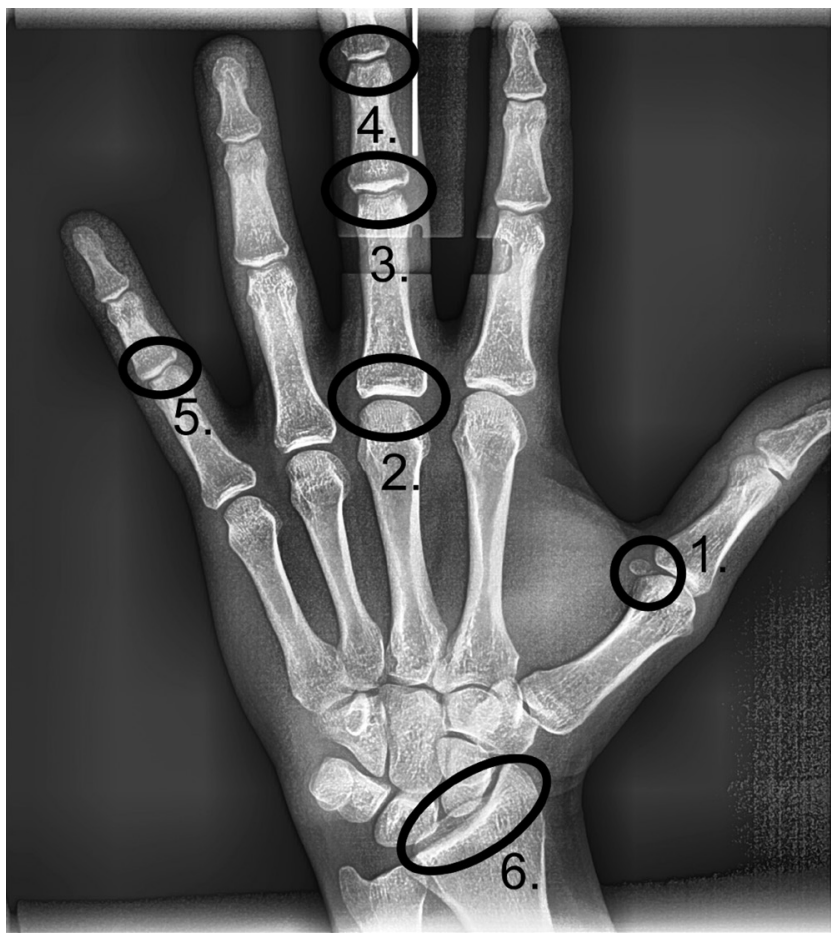

1. ábra

Kézröntgenfelvétel, melyen a Fishman által vizsgált 6 ossificatió centrum látható: szezámcsont (1.), a 3. ujj proximalis ujjperce (2.), a 3. ujj középső ujjperce (3.), a 3. ujj distalis ujjperce (4.), az 5. ujj középső ujjperce (5.), radius (6.) [3]

[2], Grave és Brown [13] is széles körben vizsgálták a kézcsontokban végbemenő változások és a szkeletális érettség, növekedés kapcsolatát. Björk 7 anatómiai pont ossificatiós változásai alapján 9 érettségi stádiumot különített el. A 3. ujj középső ujjpercének (MP3) cap stádiumánál találta a pubertáskori növekedési csúcsot [2]. Fishman 1981-ben kézröntgenfelvételeken 6 ossificatiós centrum csontosodási (1. ábra) folyamatai alapján egy újabb módszert vezetett be, az úgynevezett szkeletális maturációs indexet (SMI) [3]. Az általa vizsgált 2000 felvételnél azt tapasztalta, hogy ezen anatómiai pontok csontosodása 3 eset kivételével minden egyénben meghatározott sorrendben történik. A szkeletális maturációt a kézcsontok ossificatiós eseményei alapján így 11 stádiumba (SMIS) osztotta. Azt találta, hogy elsőként mindig a 3. ujj proximalis ujjpercét, utoljára pedig a radiust érintik a változások. A Fishman-féle csontérettségi stádiumokat és az egyes stádiumokhoz tartozó csontosodási folyamatokat az 1. táblázat szemlélteti [3]. A 11 szakasz definiálását követôen az egyes szakaszok és a testmagasság, illetve az állcsontok növekedése közti kapcsolatokat vizsgálva továbbá azt találta, hogy a lányok testmagassága az SMIS 4.-SMIS 6. között, a maxilla az SMIS 5.SMIS 6. között, az alsó állcsont pedig az SMIS 6.-SMIS 7. között éri el növekedési maximumát, míg a fiúk esetén mindhárom növekedési csúcs az SMIS 6.-SMIS 7. idejére tehető. Továbbá azt tapasztalta, hogy lányok esetén a csúcsok a kronológiai életkort tekintve mindig l-2 évvel
1. táblázat A Fishman-féle SMIS és az egyes stádiumokhoz tartozó csontosodási folyamatok a vizsgált 6 anatómiai pontra vonatkoztatva [3]

\begin{tabular}{ll}
\hline $\begin{array}{l}\text { A Fishman-féle szkeletális } \\
\text { maturációs index (SMI) }\end{array}$ & anatómiai pont SMIS szerinti változásai \\
\hline SMIS 1. & $\begin{array}{l}\text { A 3. ujj proximalis ujjpercénél } \\
\text { a metaphysis kiszélesedik }\end{array}$ \\
\hline SMIS 2. & $\begin{array}{l}\text { A 3. ujj középső ujjpercénél a metaphysis } \\
\text { kiszélesedik }\end{array}$ \\
\hline SMIS 3. & $\begin{array}{l}\text { Az 5. ujj középső ujjpercénél a metaphysis } \\
\text { kiszélesedik }\end{array}$ \\
\hline SMIS 4. & A hüvelykujjszezámcsont ossificatiója \\
\hline SMIS 5. & A 3. ujj distalis ujjpercének cap stádiuma \\
\hline SMIS 6. & A 3. ujj középső ujjpercének cap stádiuma \\
\hline SMIS 7. & $\begin{array}{l}\text { Az } 5 . \text { ujj középső ujjpercének cap } \\
\text { stádiuma }\end{array}$ \\
\hline SMIS 8. & $\begin{array}{l}\text { A 3. ujj distalis ujjperce, } \\
\text { metaphysis-diaphysis-fúzió }\end{array}$ \\
\hline SMIS 9. & $\begin{array}{l}\text { A 3. ujj proximalis ujjperce, } \\
\text { metaphysis-diaphysis-fúzió }\end{array}$ \\
\hline SMIS 10. & $\begin{array}{l}\text { A 3. ujj középső ujjperce, } \\
\text { metaphysis-diaphysis-fúzió }\end{array}$ \\
\hline SMIS 11. & Radius \\
\hline
\end{tabular}

SMIS = Fishman-féle SMI-stádiumok

korábbra esnek [3]. Van olyan módszer is, amely mindösszesen csak 2 anatómiai pontot (MP3, radius) vizsgál a kézfelvételeken [6]. A svéd populáción végzett mérések alapján kapott eredményeket és ezen csontérettségi vizsgálómódszer szempontjait a 2. táblázat foglalja össze [6].

Összességében számos módszer létezik, melyek a kézcsontok csontosodási folyamatai alapján alkalmasak a szkeletális kormeghatározásra. A kézcsontok értékelésén alapuló csontérettségi vizsgálatok legnagyobb hátránya a klinikai felhasználásban azonban, hogy külön kézröntgenfelvétel elkészítését igénylik, így azok fokozott sugárterheléssel járnak.

\section{Csigolyaanalizis}

Annak érdekében, hogy a gyakorlatban az ionizáló sugárzást a legalacsonyabb szinten tartsuk, célszerú lenne egyéb módszerek használata, melyek kiváltják a kézfelvételek elkészítésének szülkségességét. Elsőnek 1972-ben Lamparski igazolta, hogy a cervicalis (C) nyakcsigolyák változásait megbízhatóan lehet alkalmazni szkeletális kormeghatározásra a kézfelvételek helyett [7]. Életkor és nem szerinti standardokat határozott meg 5 nyaki csigolya (C2-C6) morfológiai különbségei alapján. Ezeket a csigolyastádiumokat „cervical vertebral stage (CVS)"eknek nevezte el. Összesen 6 különböző stádiumot (CVS 1-6.) tudott elkülöníteni a csigolyák alsó kontúr- 


\begin{tabular}{|c|c|c|}
\hline $\begin{array}{l}\text { A Hägg és Taranger-féle } \\
\text { csontérettségi stádiumok }\end{array}$ & 2 anatómiai pont stádiumok szerinti csontosodási változásai & Várható növekedés \\
\hline MP3-F & $\begin{array}{l}\text { A 3. ujj középső ujjperce: az epiphysis szélessége egyenlő } \\
\text { a metaphysis szélességével }\end{array}$ & $40 \%$ pubertáskori növekedés előtt \\
\hline MP3-FG & $\begin{array}{l}\text { A 3. ujj középső ujjperce: az epiphysis szélessége egyenlő } \\
\text { a metaphysis szélességével, és az epiphysis medialis vagy } \\
\text { lateralis széle a distalis széllel hegyes szöget zár be }\end{array}$ & 90\% 1 évvel a pubertáskori növekedés előtt vagy csúcson \\
\hline MP3-G & A 3. ujj középső ujjperce: az epiphysis megvastagodott & $90 \%$ a csúcson vagy utána \\
\hline MP3-H & $\begin{array}{l}\text { A 3. ujj középső ujjperce: az epiphysis és a metaphysis } \\
\text { összeolvadása megkezdődött }\end{array}$ & $\begin{array}{l}90 \% \text { lány, } 100 \% \text { fiú a csúcs után vagy a növekedés leállta } \\
\text { elött }\end{array}$ \\
\hline MP3-I & $\begin{array}{l}\text { A 3. ujj közéső ujjperce: az epiphysis és a metaphysis } \\
\text { fúziója befejeződik }\end{array}$ & $\begin{array}{l}\text { 1-2 lány kivételével mindenki a növekedés leállta előtt } \\
\text { vagy után }\end{array}$ \\
\hline R-I & $\begin{array}{l}\text { Radius: a fúzió elkezdődött a metaphysis és az epiphysis } \\
\text { között }\end{array}$ & $\begin{array}{l}80 \% \text { lány, } 90 \% \text { fiú } 1 \text { évvel a növekedés leállta előtt vagy a } \\
\text { növekedés leállta után }\end{array}$ \\
\hline R-IJ & Radius: majdnem befejeződött a fúzió, de van egy kis rés & A növekedés leállt \\
\hline R-J & Radius: a fúzió befejeződött & A növekedés leállt \\
\hline
\end{tabular}

3. táblázat |A Hassel és Farman-féle csigolyaérettségi szakaszok, a csigolyakorok szerinti csigolyamorfológiai sajátosságok, illetve az egyes szakaszoknak megfelelő SMIS-stádiumok és a hozzájuk tartozó várható növekedési mértékek [5]

\begin{tabular}{|c|c|c|c|c|}
\hline A stádium elnevezése & $\begin{array}{l}\text { Fishman-féle } \\
\text { szkeletális kor }\end{array}$ & $\begin{array}{l}\text { Jellemző csigolyamorfológia } \\
\text { A csigolya alsó kontúrja }\end{array}$ & $\begin{array}{l}\text { Jellemző csigolyamorfológia } \\
\text { A csigolyatest alakja }\end{array}$ & Várható növekedés \\
\hline Iniciáció & SMIS 1., 2 & C2, C3, C4 alsó kontúrja lapos & Csigolyatestek trapéz alakja & $\begin{array}{l}\text { Növekedés 80-100\%-a } \\
\text { várható }\end{array}$ \\
\hline Akceleráció & SMIS 3., 4 . & $\begin{array}{l}\text { C2, C3 behúzódása megjelenik, } \\
\text { C4 lapos }\end{array}$ & C3, C4: majdnem téglalap & $\begin{array}{l}\text { Növekedés } 65-85 \% \text {-a } \\
\text { várható }\end{array}$ \\
\hline Tranzíció & SMIS 5., 6. & $\begin{array}{l}\text { C2, C3 kifejezett behúzódása, } \\
\text { C4 is behúzódik }\end{array}$ & C3, C4: téglalap & $\begin{array}{l}\text { Növekedés 25-65\%-a } \\
\text { várható }\end{array}$ \\
\hline Deceleráció & SMIS 7., 8 . & C2, C3, C4 behúzódása & C3, C4: négyzetszerü & $\begin{array}{l}\text { Növekedés 10-25\%-a } \\
\text { várható }\end{array}$ \\
\hline Maturáció & SMIS 9., 10. & C2, C3, C4 kifejezett behúzódása & C3, C4: négyzet & Növekedés 5-10\%-a várható \\
\hline Kompléció & SMIS 11. & C2, C3, C4 mély behúzódása & C3, C4: álló téglalap & Befejeződött a növekedés \\
\hline
\end{tabular}

SMIS = Fishman-féle SMI-stádiumok

vonalát és a csigolyatesteket érintő változások figyelembevételével. Továbbá azt találta, hogy a pubertáskori növekedési csúcs a CVS 3. és a CVS 4. stádium között van [7]. Később, 1988-ban O’Reilly és Yanniello a Lamparski-féle csigolyaérettségi stádiumok és a mandibulanövekedés közvetlen kapcsolatát vizsgálták [9]. A BoltonBroadbent Growth Study adatállományát felhasználva arra a következtetésre jutottak, hogy nemcsak a testmagasság, de mind a mandibula teljes hosszának, mind a corpus hosszának, mind pedig a ramus magasságának növekedésbeli változásai a CVS 3., illetve a CVS 4. stádium között érik el maximumukat, illetve a CVS 2. és a CVS 3. körülbelül a csúcs előtt l évvel várható [9]. Majd 7 évvel később Hassel és Farman egy olyan újfajta csontérettségi vizsgálómódszert dolgozott ki, melyet a mindennapi gyakorlatban is rutinszerúen alkalmazni lehet [5]. Már csak a C2-es, a C3-as és a C4-es nyakcsigolya morfológiai változásait követték nyomon, mivel ezek a csigolyák az oldalirányú teleröntgenfelvételeken mindig, minden körülmények között, még pajzsmirigyvédő használata mellett is jól látszanak. A csigolyamorfológia és a Fishman-féle SMIS között talált összefüggések szerint 6 csigolyaérettségi fázist definiáltak. A kézfelvételek alapján az egyes csontérettségi korokhoz tartozó várható növekedési mértékeket is meghatározták, és ezek szerint nevezték el az egyes csigolyastádiumokat; iniciáció, akceleráció, tranzíció, deceleráció, maturáció, kompléció (3. táblázat) [5]. Az egyes stádiumokra jellemző morfológiai sajátosságokat a 2. ábra szemlélteti [5].

Ezt követően, 2002-ben Baccetti munkacsoportja továbbfejlesztette és leegyszerúsítette a Hassel és Farmanféle csigolyaanalízis szerinti csontkor-meghatározást, és megalkották az úgynevezett „cervical vertebral maturation stage"-eket (CVMS) [1]. A Michigan Growth Study-ból rendelkezésre álló olyan alanyokat válogattak ki a vizsgálatukba, akiknek minimum 6 oldalirányú tele- 


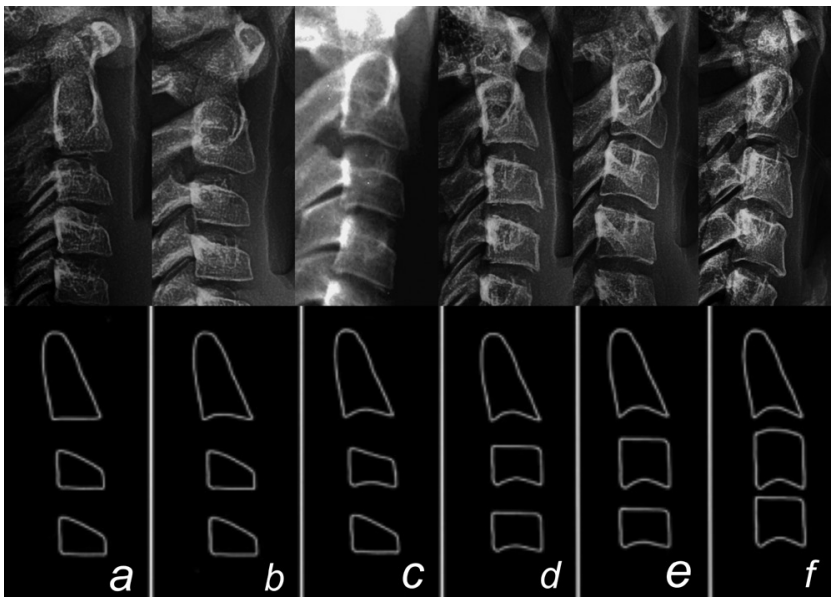

2. ábra

A Hassel és Farman-féle csigolyaérettségi stádiumok a C2-es, a C3-as és a C4-es nyakcsigolya morfológiai sajátosságai alapján iniciáció (a), akceleráció (b), tranzíció (c), deceleráció (d), maturáció (e), kompléció (f) [5]

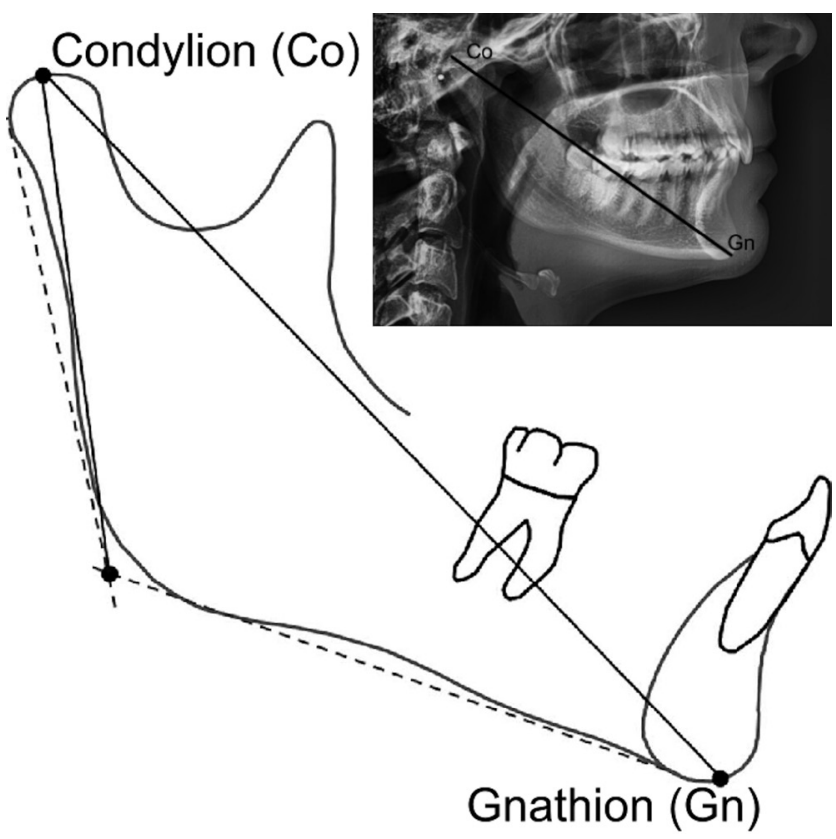

3. ábra Condylion-gnathion-távolság; condylion: a mandibulafejecs
legfelső, leghátsó pontja; gnathion: a sella turcica középpontjá-
tól az állcsúcs legtávolabbi pontjához húzott egyenesnek a man-
dibula kontúrjával alkotott metszéspontja; condylion-gnathion-
távolság: a condylion- és gnathionpontokat összekötő egyenes
hossza

röntgenfelvétele rendelkezésre állt. A röntgeneken értékelték a condylion-gnathion-távolság (3. ábra) változásait: amely két időpontban készült felvétel között ezen távolságbeli változás a legnagyobb volt, azt tekintették a maximális mandibulanövekedésnek (mandibularis növekedési csúcs). Utána a vizsgálatba már csak azokat az egyéneket vonták be, akiknél mind a csúcs előtt, mind a csúcs után legalább 2-2 további röntgenfelvétel rendelkezésre állt. Így a kezdeti 706 vizsgálati alanyból mindösszesen 30 maradt. A felvételeken a C2-es, a C3-as és a
C4-es csigolya alakbeli változásai és a mandibula maximális növekedése közötti összefüggéseket nézték. Arra a következtetésre jutottak, hogy az alsó állcsont növekedése szempontjából szükségtelen a korábbi CVS 1. és CVS 2. között különbséget tenni, elég csak 5 csigolyaérettségi szakaszt elkülöníteni. Így született meg a klinikai gyakorlatban napjainkban a leggyakrabban alkalmazott 5 stádiumos Baccetti-féle CVMS csigolyaérettségi vizsgálómódszer, melyre vonatkozó részleteket a 4. táblázat szemlélteti [1].

A csigolyák analízisén alapuló módszerek egyik legnagyobb hátránya, hogy a mérések sokak szerint nehezen reprodukálhatók [14-17]. A reprodukálhatósági problémák leggyakoribb okaként elsósorban a vizsgálók nem megfelelő számát, azoknak a témában való különböző mértékű jártasságát és a csigolyatestek alakjának szubjektív megítélési nehézségét említik [15-18].

Annak érdekében, hogy a csigolyák alakbeli változásait minél objektívebben lehessen megítélni, 2008-ban Chen és mtsai újabb, kvantitatív csigolyaérettségi vizsgálómódszert (quantitative cervical vertebral maturation [QCVM]) publikáltak [19]. Módszerük lényege az volt, hogy bizonyos mérőpontok definiálásával méréseket végeztek a 2., a 3. és a 4. nyakcsigolyán. Elsősorban csigolyaszélességet, csigolyamagasságot, alsóbehúzódás-mélységet és az ezek arányait számszerüen meghatározó paramétereket tanulmányoztak. A vizsgált 42 paraméterból 30 mutatott pozitív korrelációt a Fishman-féle szkeletális korokkal. A kézfelvételek stádiumai szerint a növekedést 4 egymástól jól elkülöníthető szakaszra bontották: pubertás, növekedés előtti (SMIS 1.-SMIS 3.), pubertáskori növekedési csúcs (SMIS 4.-SMIS 7.), pubertás utáni deceleráció (SMIS 8.-SMIS 9.) és a növekedés vége (SMIS 10.-SMIS 11.). Majd ezekre a szakaszokra vonatkoztatva kiszámolták a 3 kiválasztott, legszorosabb összefüggést mutató mérési paraméter kvantitatív standardjait (5. táblázat), és az összefüggésekre alapozva megalkottak egy regressziós egyenletet, melynek segítségével a szkeletális kor kvantitatív módon meghatározható [19].

A csigolyamorfológiai változások nyomon követésére az oldalirányú teleröntgenek kiváló lehetőséget nyújtanak. A vizsgálatok legnagyobb előnye, hogy egy fogszabályozó kezelés kapcsán a röntgenfelvételek elkészítése a rutin diagnosztikai eljárások közé tartozik, így szinte kivétel nélkül majdnem mindig rendelkezésünkre állnak.

\section{A fogazati fejlettség alapján történö meghatározás}

Amennyiben az ionizáló sugárzást a legalacsonyabban szeretnénk tartani, felmerül a panoráma-röntgenfelvételek vagy akár a kisröntgenfelvételek használatának létjogosultsága is, melyeken egyrészről vizsgálható a fogak erupciós stádiuma, másrészról pedig a fogak mineralizáltsági foka is. Míg a fogak előtörési sorrendjét számos külső környezeti hatás - kariológiai status, állcsonton 
4. táblázat | A Baccetti és mtsai által definiált csigolyaérettségi stádiumok, csigolyamorfológiai sajátosságok, illetve az egyes szakaszoknak megfelelő maximális mandibularis növekedés várható ideje [1]

\begin{tabular}{llll}
\hline Stádium & Alsó kontúr, konvexicitás & Csigolyatest & Mandibulanövekedési csúcs \\
\hline CVMS I. & $\begin{array}{l}\text { C2, C3, C4 alsó kontúrja lapos, } \\
\text { esetleg a C2 alsó kontúrján behúzódás } \\
\text { (az esetek 50\%-ában) }\end{array}$ & C3, C4: trapéz alak & éven belül nem várható \\
\hline CVMS II. & C2, C3 alsó kontúrján behúzódás & C3, C4: trapéz alak vagy fekvő téglalap & 1 éven belül várható \\
\hline CVMS III. & C2, C3, C4 alsó kontúrján behúzódás & C3, C4: fekvő téglalap & 1 vagy 2 éven belül volt \\
\hline CVMS IV. & C2, C3, C4 alsó kontúrján behúzódás & C3 vagy C4: négyzet alakú már, de lehet & Nem több, mint 1 éve volt \\
\hline CVMS V. & C2, C3, C4 alsó kontúrján behúzódás & $\begin{array}{l}\text { C3 vagy C4: már álló téglalap, de lehet } \\
\text { az egyik még négyzet }\end{array}$ & Nem több, mint 2 éve volt \\
\hline
\end{tabular}

5. táblázat $\mid$ A Chen és munkacsoportja által meghatározott Fishman-féle SMIS szerinti növekedési szakaszokhoz tartozó kvantitatív csigolyaérettségi stádiumok, illetve az általuk kiválasztott paramétereknek $(\mathrm{H} 4 / \mathrm{W} 4$ = a 4 . nyaki csigolyánál mért középső csigolyamagasság és a 4 . nyaki csigolyánál mért középső csigolyaszélesség aránya; $\mathrm{AH} 3 / \mathrm{PH} 3$ = a 3 . nyaki csigolyánál mért elülső csigolyamagasság és a 3 . nyaki csigolyánál mért hátulsó csigolyamagasság aránya; @2 = a 2 . nyaki csigolya alsó behúzódásának legmélyebb pontja és a hátulsó alsó csigolyapont, illetve a hátulsó alsó csigolyapont és az elülső alsó csigolyapont által meghatározott egyenesek által bezárt szög) az egyes stádiumokhoz tartozó számolt értékei [19]

\begin{tabular}{llllcc}
\hline QCVM & Fishman-féle SMIS & Növekedési szakasz & \multicolumn{2}{c}{ A legszorosabb összefüggést mutató változók kvantitatív standardjai } \\
\cline { 3 - 6 } & & & H4/W4 [\%] & AH3/PH3 [\%] & $@ 2\left[{ }^{\circ}\right]$ \\
\hline I. & SMIS 1-3. & Akceleráció & $0,63 \pm 0,07$ & $0,72 \pm 0,05$ & $7,17 \pm 3,03$ \\
\hline II. & SMIS 4-7. & Pubertáskori növekedési csúcs & $0,74 \pm 0,06$ & $0,80 \pm 0,04$ & $12,65 \pm 3,26$ \\
\hline III. & SMIS 8-9. & Deceleráció & $0,84 \pm 0,05$ & $0,85 \pm 0,03$ & $15,63 \pm 3,24$ \\
\hline IV. & SMIS 10-11. & A növekedés vége & $0,98 \pm 0,07$ & $0,98 \pm 0,06$ & $20,81 \pm 3,35$ \\
\hline
\end{tabular}

SMIS = Fishman-féle SMI-stádiumok

belüli helyviszonyok, ankylosis, etnikai hovatartozás - is befolyásolhatja, addig a kalcifikációs stádiumok mindezektől függetlenek [20]. A vizsgálatok is egyértelműen azt mutatják, hogy sem a fogak előtörésének sorrendje, sem a tejfogak (második tejőrlő) elvesztése, sem pedig a fogazati stádiumok (tejfogazat, vegyes fogazat, maradó fogazat) nem függenek össze a szkeletális érettséggel $[18,21]$. Az igazságügyi orvostanban a fogazati kornak, illetve az egyes fogak mineralizáltsági szintjének a meghatározására a leggyakrabban a Demirjian-féle klasszifikációs beosztást használjuk [22, 23], mely a kezdeti csücsökcsúcs-elmeszesedéstől a gyökércsúcs teljes záródásáig összesen 8 stádiumot különít el (4. ábra) [22]. Az alsó bölcsességfogak, az alsó második őrlőfogak és az alsó szemfogak vizsgálata bizonyult mind ez idáig a legmegbízhatóbbnak. A felső fogak értékelését megnehezíti a különböző anatómiai képletek egymásra vetülése, így azokat nemigen használják [24]. Az alsó második molaris fog legnagyobb előnye, hogy fejlődése relatíve hosszú ideig, akár 16 éves korig is eltart, továbbá ez az időszak pont a növekedési csúcs környékére esik [24]. A Demirjian-féle módszer kormeghatározásra használható diagnosztikus megbízhatóságának igazolására elsősorban a kézcsont-, illetve a csigolyaérettségi vizsgálómódszereket alkalmazzák. A kapott eredmények azonban meglehetősen ellentmondásosak [24-29]. A nyakcsigolyák tekintetében Kumar és mtsai [24], Giri és mtsai [25]

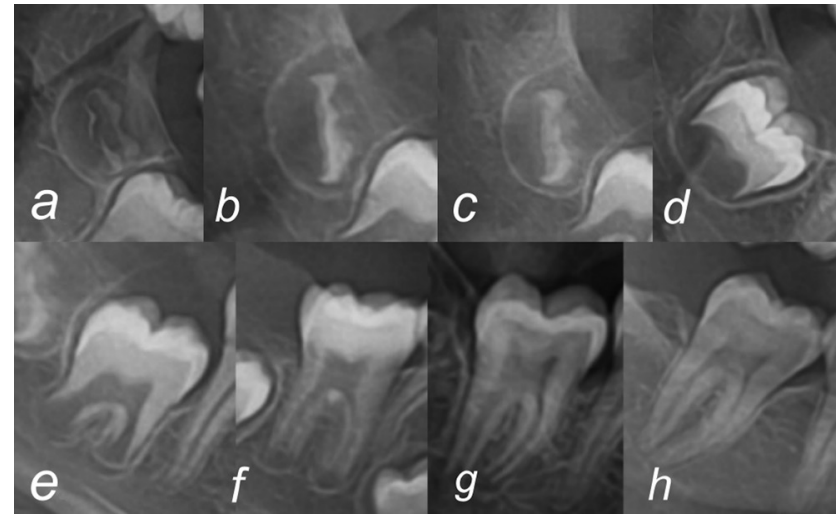

\begin{tabular}{l|l} 
4. ábra & A Demirjian-féle osztályozás és stádiumai, mely nyolc fejlődési
\end{tabular} szakaszt különböztet meg a kezdeti csücsökcsúcs elmeszesedésétől a komplett gyökércsúcs záródásáig: (a) a csücsökcsúcsok elmeszesedtek, (b) az elmeszesedett csücsökcsúcsok egyesültek, (c) a fog koronájának fele kifejlődött, (d) a fog koronája teljesen kifejlődött, (e) a bifurkáció fejlődése elkezdődött, de a gyökér hossza rövidebb, mint a korona hossza, (f) a gyökér hossza legalább olyan hosszú, mint a korona hossza; a gyökerek tölcsérformában végződnek, (g) a gyökerek falai párhuzamosak, de az apexek nyitottak, (h) az apexek záródtak [22]

továbbá Cossellu és mtsai [26] is szoros összefüggést mutattak ki a Demirjian-féle fogazati korok és a csontérettségi korok között. Nayak és munkacsoportja [20] pedig a kézcsontok érettségi stádiumaihoz viszonyítva vont le hasonló következtetéseket. Mások épp ellenkezőleg, azt 
találták, hogy a szkeletális kor és a várható növekedés nem áll kapcsolatban a fogak kalcifikációs szintjeivel [2729]. A jelenleg rendelkezésre álló adatok alapján úgy tünik, hogy más módszerek hatékonyabb eszközként szolgálnak a csontérettség és a növekedési csúcsok meghatározásában.

\section{Modern vizsgálómódszerek}

\section{Háromdimenziós (3D) képalkotó eljárásokra épüló vizsgálómódszerek}

Mivel a növekedés nem két dimenzióban (2D), hanem térben történik, továbbá bizonyított, hogy a tér három irányának megfelelően meghatározott sorrendben és eltérő ütemben zajlik, így adja magát a lehetőség, hogy a háromdimenziós (3D) képalkotó eljárások által kínált információtöbbletet is kihasználjuk. Choi és mtsai olyan módszert dolgoztak ki, amelynek alapján a csigolyák térfogatváltozásaiból következtethetünk a csontkorra [30]. Cone-beam CT (CBCT)-felvételeken a C2-es, a C3-as és a C4-es nyaki csigolya térfogati paraméterei és a kézfelvételeken bekövetkező csontosodási változások összefüggéseit vizsgálva azt találták, hogy a C3-as és a C4-es térfogatváltozásai szoros, lineáris korrelációt mutatnak a csontérettséggel. A C2-es csigolya tekintetében nemigen sikerült kapcsolatot kimutatni, amit azzal magyaráztak, hogy a 2. nyaki csigolya hajlamos a leginkább a remodellálódásra a növekedés folyamán. Több szerző is egyetért abban, hogy a CBCT-felvételekből készített 2D, sagittalis metszeti felvételek és a csigolyákról készült 3D-rekonstrukciók is ugyanolyan jól alkalmazhatók, mint az oldalirányú teleröntgenek $[10,31]$. Eszerint bármely klasszikus csigolyavizsgálati analízis szempontrendszerét felhasználva ugyanolyan pontos megbízhatósággal meghatározhatunk csontérettséget a 3D-felvételeken is.

Vannak olyan próbálkozások is, amelyek a korábbi 2D-röntgenfelvételekre épülő kvantitatív csigolyaérettségi eljárásokat próbálják CBCT-felvételekre átültetni [32]. A módszer legnagyobb előnye, hogy CBCT-felvételeken lehetőség van a dentocentralis synchondrosis vizualizálására, így a 2. csigolyatest és a processus odontoideus pontos elkülönítésével a 2D-felvételekhez képest további paraméterek vizsgálhatók. Byun munkacsoportjával japán fiúkra és lányokra vonatkoztatva is megalkotott 1-1 olyan regressziós egyenletet, amelyben mérhető csigolyamorfológiai paraméterekből következtethetünk a csontérettségre. Azonban az egyenlet gyakorlati alkalmazására még nincs konkrét útmutató [32].

CBCT-felvételeken nemcsak a csigolyák, hanem egyéb anatómiai képletek is segítségünkre lehetnek a csontérettség meghatározásában [33-40]. Bassed munkatár saival egy a craniofacialis régió növekedése szempontjából rendkívül fontos képletnek, a sphenooccipitalis synchondrosisnak a fúzióját tanulmányozta annak érdekében, hogy a kormeghatározásban igazságügyi orvosoknak segítséget nyújtson [36]. Vizsgálataiban 5 különbö- ző, egymástól jól elkülöníthető stádiumot talált (A - a synchondrosis nyitott, $\mathrm{B}$ - a fúzió a felsô póluson elkezdődött, C - a synchondrosis fele fuzionált, D - teljes fúzió, de a fúziós heg látszik, E - a fúziós heg eltünt, kompakt csont). Bár a stádiumbeosztást csak 11-17 éves kor között lehet megbízhatóan alkalmazni [36], a pubertáskori növekedési csúcs meghatározása tekintetében még potenciális módszernek mutatkozik. FernándezPérez munkacsoportja CBCT-felvételeken szoros kapcsolatot talált a csigolyaérettségi stádiumok és a synchondrosis fúziója között. Szignifikáns összefüggést találtak a synchondrosis $50 \%$-os fuzionáltsági szintje és a pubertáskori növekedési csúcs között [37].

A sutura palatina mediana fúziós változásait is átfogóan vizsgálták [33-35]. A sutura interdigitatiói az idő előrehaladtával fokozódnak [41], egészen addig, amíg a fúzió teljes nem lesz. Ennek a morfológiai változásnak klinikai szempontból elsősorban a szúk felső állcsont transzverzális tágításakor van nagy jelentősége, ugyanis az interdigitatiók fokozódásával a transzverzális problémákat csak sebészileg megtámogatva, inkomplett Le Fort I-es mütéttel és pterygomaxillaris diszjunkcióval kiegészítve lehet elvégezni [42]. A mütéti beavatkozás idejére vonatkozóan sokáig nem volt egységes állásfoglalás. A kronológiai kor pontatlannak bizonyult a sebészi támogatás megítélése szempontjából [33], így az lenne ideális, ha minden páciens suturaérettségi fokát egyénileg tudnánk meghatározni. A CBCT-felvételeket tanulmányozva összesen 5 érési stádiumra bontható a palatinalis sutura maturációja (6. táblázat) $[34,35]$. Angelieri és mtsai elsőként demonstrálták, hogy a suturamaturáció és a nyaki csigolyák alapján mért csontérettségi korok egymással kapcsolatban állnak [34]. Azt találták, hogy CVMS 1-2.-ben a sutura A vagy B érettségi stádiumban van, CVMS 3.-ban C, még CVMS 4. és 5. esetén C, D és E stádium egyaránt előfordult. CVMS 5.-ben a vizsgált alanyok 13,5\%-a még C stádiumban volt. Minthogy ezt követően a D stádiumban, a fúzió megvalósulásával szükségessé válik a sebészi beavatkozás, az eredmények alapján a felső állcsont transzverzális kezelésére egy ajánlott kezelési protokollt is felvázoltak. Amennyiben egy adott egyént CVMS 4-es vagy 5-ös csigolyaérettségi stádiumban diagnosztizálunk, indokolt CBCT-felvétel készítése annak érdekében, hogy a palatinalis csontvarrat állapotáról egyénileg informálódjunk [33]. Eredményeiket, illetve ajánlásukat a 6. táblázat szemlélteti [34, 35].

A sinus frontalis morfológiája és légtartó kapacitása a növekedés során változik [38]. Vannak próbálkozások, amelyek az ezen változásokra épülő csontkormeghatározó módszereket próbáltak kifejleszteni [11, 39]. Sem a sinus magasságának, sem szélességének, sem pedig e kettő hányadosának, az úgynevezett sinusindexnek sem sikerült beváltani a hozzá füzött reményeket [11, 39]. A nyelvcsont morfológiai vizsgálatai ugyancsak sikertelennek bizonyultak a szkeletális érettség meghatározásának tekintetében [40]. 
Az Angelieri és mtsai által meghatározott sutura palatina mediana maturációs stádiumok és a Baccetti-féle szkeletális csontkor közötti összefüggések, illetve az ezen stádiumokhoz kapcsolódó ajánlott kezelési protokollok [34, 35]

\begin{tabular}{llll}
\hline $\begin{array}{l}\text { Sutura palatina mediana } \\
\text { maturációs stádiumok }\end{array}$ & $\begin{array}{l}\text { Sutura palatina a CBCT-felvételen } \\
\text { A stádium }\end{array}$ & $\begin{array}{l}\text { Egyszeres, egyenes magas denzitásús protokoll } \\
\text { vonal }\end{array}$ & $\begin{array}{l}\text { Lassú, gyors tágítás } \\
\text { féle csigolyanalízis alapján }\end{array}$ \\
\hline B stádium & $\begin{array}{l}\text { Egyszeres, csipkézett magas } \\
\text { denzitású vonal }\end{array}$ & Lassú, gyors tágítás & CVMS I-II. \\
\hline C stádium & $\begin{array}{l}\text { Két párhuzamos csipkézett magas } \\
\text { denzitású vonal, helyenként alacsony } \\
\text { denzitású szakaszokkal }\end{array}$ & $\begin{array}{l}\text { Lassú, gyors tágítás, de kevesebb a szkeletális } \\
\text { hatás interdigitatiók miatt }\end{array}$ & CVMS III. \\
\hline D stádium & A fúzió teljes, nem látható a sutura & Sebészileg támogatott rapid maxillaris expanzió & CVMS IV-V. \\
\hline E stádium & Az anterior fúzió is teljes & Sebészileg támogatott rapid maxillaris expanzió & CVMS IV-V. \\
\hline
\end{tabular}

CBCT = cone-beam komputertomográfia; CVMS = Baccetti-féle csigolyaérettségi stádium

Összességében a 3D képalkotó eljárások előnyös tulajdonságaik miatt számos fogászati és fül-orr-gégészeti alkalmazás mellett [43] ugyancsak kiváló lehetőséget nyújtanak napjainkban a szkeletális érettség meghatározására.

\section{Vérminta, vizelet és sulcusfolyadék vizsgálata}

A vér, a különböző testváladékok és szövetnedvek ugyancsak lehetőséget nyújtanak, hogy olyan biomarkereket azonosítsunk, amelyek mennyisége szorosan korrelál a növekedés ütemével. A növekedési hormon $(\mathrm{GH})$ mint a növekedés legalapvetőbb irányítója potenciális lehetőséget kínál. Szintje bizonyítottan emelkedett a pubertáskori növekedési időszakban, mennyisége azonban napszaki ingadozást mutat, s emiatt nem használható megbízhatóan [44]. Ezzel szemben az inzulinszerû növekedési faktor-1 (IGFl) termelődését a GH stimulálja, továbbá a GH hatásának elsődleges mediátora - szintje nem fluktuál úgy, mint a GH-é, így sokkal megbízhatóbb módszernek mutatkozik [44]. Számos munkacsoport végzett vizsgálatokat, hogy a szérum-IGFl (seIGFl) és a radiológiai módszerekkel mért szkeletális korok közötti összefüggésekből következtessenek a növekedés ütemére [4448]. Ishaq és mtsai szoros korrelációt találtak az egyes csigolyaérettségi stádiumok és a seIGFl között. Fiúk és lányok esetén is a Hassel és Farman-féle 4. csigolyaérettségi stádiumnál találták a legmagasabb hormonszinteket, azonban a nemi különbségeket figyelembe véve lányoknál már korábban kezdődött, fiúknál pedig tovább tartott az IGFl-növekedés [45]. Sinba és mtsai is ezzel megegyező eredményre jutottak, ők azonban nemcsak szérum-, hanem vizeletmintákat is vizsgáltak, melyek ugyanolyan jónak bizonyultak. Továbbá a vizeletvizsgálat legnagyobb előnye, hogy a mintavétel noninvazív [46]. A mások által publikált eredmények annyiban különböznek, hogy a két nem közötti különbségek jobban megmutatkoztak, mivel a lányoknál a 3., míg fiúknál a 4 . csigolyaérettségi korban mérték a legmagasabb IGFl-értékeket $[46,47]$. Összességében elmondható, hogy a mért IGFl-szintek tendenciái hasonlók (IGFl-növekedés, -csúcs, majd -csökkenés), továbbá egyetértés van a tekintetben is, hogy a lányok esetén a növekedési csúcs korábbra tehető. A seIGFI dinamikája tehát megbízhatónak mutatkozik, egyedül a csúcsok időpontja tekintetében vannak eltérések, mely különbségek feltehetően a vizsgált csoportok etnikai különbségeire vezethetôk viszsza. Emiatt javasolt lehet a jövőben populációspecifikus standardokat létrehozni. A vérplazmában és szöveti váladékokban továbbá jelen vannak egyéb növekedést serkentő, illetve a csontmetabolizmus szempontjából fontos anyagok. Az IGFl jelentôs része a keringésben az IGFl-kötő fehérjékhez (IGFBP) kötött állapotban van, és ebből a kötések mintegy $80 \%$-áért az IGFBP3 felel [44]. Az IGFBP3-szint mérésével így informálódhatunk az IGFl biológiai aktivitásáról. Jain és mtsai potenciális lehetőséget látnak ezen kötőfehérjék detektálásában, mivel mennyiségük szoros összefüggést mutatott a csigolyaérettségi stádiumokkal [44]. Tripathi és munkacsoportja osteocalcin [48] és csontspecifikus alkalikus foszfatáz [49] tekintetében talált ígéretes eredményeket, még mások a gingivalis sulcus váladék proteomikai elemzése kapcsán találtak a pubertás alatt szignifikánsan magasabb seroserotransferrin- és D-vitamin-kötő-fehérjeszinteket [50]. Mindezek alapján elmondhatjuk, hogy a szkeletális érettség meghatározása szempontjából a különböző szövetnedvekben jelen lévő biomarkerek még számos kiaknázatlan lehetőséget rejtenek, így nem meglepő, hogy egyre felkapottabb kutatási terültetnek is számítanak.

\section{Következtetés}

A szkeletális kormeghatározás mind az antropológia, igazságügyi orvostan, gyermekgyógyászat, endokrinológia, mind pedig az állcsont-ortopédiai kezelések megfelelő időzítése és sikere szempontjából kiemelt jelentőséggel bír. Jelenleg számos módszer áll rendelkezésünkre, melyek segítségével a biológiai kor diagnosztizálható. Többségük 2D, illetve 3D képalkotó eljárásokra épül. 
A kézcsontok és a nyaki csigolyák morfológiai változásait vizsgáló módszerek a legelterjedtebbek, azonban egyre intenzívebb kutatások folynak, hogy a jövőben a biológiai kor meghatározására egyéb módszereket is alkalmazzunk, melyek a különböző, a keringésben vagy egyéb, testváladékban jelen lévő biomarkerek mérésén alapulnak. A jelenleg rendelkezésre álló adatok alapján azonban ezen legutóbbi, bemutatott módszerek megbízhatóságának minden kétséget kizáró bizonyítására még további vizsgálatok szükségesek.

Anyagi támogatás: A közlemény megírása, illetve a kapcsolódó kutatómunka anyagi támogatásban nem részesült.

Szerzői munkamegosztás: A dolgozat elkészítésében mind a négy szerző egyenlő arányban vett részt. A cikk végleges változatát valamennyien elolvasták és jóváhagyták.

Érdekeltségek: A szerzőknek nincsenek érdekeltségeik.

\section{Irodalom}

[1] Baccetti T, Franchi L, McNamara JA Jr. An improved version of the cervical vertebral maturation (CVM) method for the assessment of mandibular growth. Angle Orthod. 2002; 72: 316-323.

[2] Björk A, Helm S. Prediction of the age of maximum puberal growth in body height. Angle Orthod. 1967; 37: 134-143.

[3] Fishman LS. Radiographic evaluation of skeletal maturation. A clinically oriented method based on hand-wrist films. Angle Orthod. 1981; 52: 88-112.

[4] Greulich WW, Pyle SI. Radiographic atlas of skeletal development of the hand and wrist. Second edition. Stanford University Press, Stanford, CA, 1959.

[5] Hassel B, Farman A. Skeletal maturation evaluation using cervical vertebrae. Am J Orthod Dentofacial Orthop. 1995; 107: $58-66$.

[6] Hägg U, Taranger J. Maturation indicators and the pubertal growth spurt. Am J Orthod. 1982; 82: 299-309.

[7] Lamparski DG. Skeletal age assessment utilizing cervical vertebrae [master's thesis]. University of Pittsburgh, Pittsburgh, PA, 1972.

[8] Kórász K. Asylum-seekers' mental and physical health problems: practices and recommendations. [A menedékkérők mentális és fizikai egészségproblémái: gyakorlatok és ajánlások.] Orv Hetil. 2016; 157: 23-29. [Hungarian]

[9] O'Reilly MT, Yanniello GJ. Mandibular growth changes and maturation of cervical vertebrae - a longitudinal cephalometric study. Angle Orthod. 1988; 58: 179-184.

[10] Joshi V, Yamaguchi T, Matsuda Y, et al. Skeletal maturity assessment with the use of cone-beam computerized tomography. Oral Surg Oral Med Oral Pathol Oral Radiol. 2012; 113: 841849 .

[11] Mahmood HT, Shaikh A, Fida M. Association between frontal sinus morphology and cervical vertebral maturation for the assessment of skeletal maturity. Am J Orthod Dentofacial Orthop. 2016; 150: 637-642.

[12] Todd TW. Atlas of skeletal maturation. Part I. Hand. Kimpton, London, 1937.

[13] Grave K, Brown T. Skeletal ossification and the adolescent growth spurt. Am J Orthod. 1976; 69: 611-619.
[14] Engel TP, Renkema AM, Katsaros C, et al. The cervical vertebrae maturation (CVM) method cannot predict craniofacial growth in girls with Class II malocclusion. Eur J Orthod. 2016; 38: 1-7.

[15] Gabriel DB, Southard KA, Qian F, et al. Cervical vertebrae maturation method: poor reproducibility. Am J Orthod Dentofacial Orthop. 2009; 136: 478.el-e7; discussion: 478-480.

[16] Nestman TS, Marshall SD, Qian F, et al. Cervical vertebrae maturation method morphologic criteria: poor reproducibility. Am J Orthod Dentofacial Orthop. 2011; 140: 182-188.

[17] Sohrabi A, Babay Ahari S, Moslemzadeh H, et al. The reliability of clinical decisions based on the cervical vertebrae maturation staging method. Eur J Orthod. 2016; 38: 8-12.

[18] Franchi L, Baccetti T, De Toffol L, et al. Phases of the dentition for the assessment of skeletal maturity: a diagnostic performance study. Am J Orthod Dentofacial Orthop. 2008; 133: 395-400.

[19] Chen LL, Xu TM, Jiang JH, et al. Quantitative cervical vertebral maturation assessment in adolescents with normal occlusion: a mixed longitudinal study. Am J Orthod Dentofacial Orthop. 2008; 134: 720.el-720.e7; discussion: 720-721.

[20] Nayak R, Nayak UK, Hegde G. Assessment of growth using mandibular canine calcification stages and its correlation with modified MP3 stages. Int J Clin Pediatr Dent. 2010; 3: 27-33.

[21] Baccetti T, Franchi L, De Lisa S, et al. Eruption of the maxillary canines in relation to skeletal maturity. Am J Orthod Dentofacial Orthop. 2008; 133: 748-751.

[22] Demirjian A, Goldstein H, Tanner JM. A new system of dental age assessment. Hum Biol. 1973; 45: 211-227.

[23] Jain V, Kapoor P, Miglani R. Demirjian approach of dental age estimation: abridged for operator ease. J Forensic Dent Sci. 2016; 8: 177.

[24] Kumar S, Singla A, Sharma R, et al. Skeletal maturation evaluation using mandibular second molar calcification stages. Angle Orthod. 2012; 82: 501-506.

[25] Giri J, Shrestha BK, Yadav R, et al. Assessment of skeletal maturation with permanent mandibular second molar calcification stages among a group of Nepalese orthodontic patients. Clin Cosmet Investig Dent. 2016; 8: 57-62.

[26] Cossellu G, Biagi R, Pisani L, et al. Relationship between mandibular second molar calcification stages and cervical vertebrae maturity in Italian children and young adults. Eur J Paediatr Dent. 2014; 15: 355-359.

[27] Surendran S, Thomas E. Tooth mineralization stages as a diagnostic tool for assessment of skeletal maturity. Am J Orthod Dentofacial Orthop. 2014; 145: 7-14.

[28] Perinetti G, Contardo L. Reliability of growth indicators and efficiency of functional treatment for skeletal class II malocclusion: current evidence and controversies. Biomed Res Int. 2017; 2017: 1367691.

[29] Perinetti G, Sossi R, Primozic J, et al. Diagnostic reliability of mandibular second molar maturation in the identification of the mandibular growth peak: A longitudinal study. Angle Orthod. 2017; 87: 665-671.

[30] Choi YK, Kim J, Yamaguchi T, et al. Cervical vertebral body's volume as a new parameter for predicting the skeletal maturation stages. Biomed Res Int. 2016; 2016: 8696735.

[31] Bonfim MA, Costa AL, Fuziy A, et al. Cervical vertebrae maturation index estimates on cone beam CT: 3D reconstructions vs sagittal sections. Dentomaxillofac Radiol. 2016; 45: 20150162.

[32] Byun BR, Kim YI, Yamaguchi T, et al. Quantitative skeletal maturation estimation using cone-beam computed tomographygenerated cervical vertebral images: a pilot study in 5- to 18-yearold Japanese children. Clin Oral Investig. 2015; 19: 2133-2140.

[33] Angelieri F, Franchi L, Cevidanes LH, et al. Prediction of rapid maxillary expansion by assessing the maturation of the midpalatal suture on cone beam CT. Dental Press J Orthod. 2016; 21: $115-125$

[34] Angelieri F, Franchi L, Cevidanes LH. Diagnostic performance of skeletal maturity for the assessment of midpalatal suture matu- 
ration. Am J Orthod Dentofacial Orthop. 2015; 148: 10101016.

[35] Angelieri F, Cevidanes LH, Franchi L, et al. Midpalatal suture maturation: classification method for individual assessment before rapid maxillary expansion. Am J Orthod Dentofacial Orthop. 2013; 144: 759-769.

[36] Bassed RB, Briggs C, Drummer OH. Analysis of time of closure of the spheno-occipital synchondrosis using computed tomography. Forensic Sci Int. 2010; 200: 161-164.

[37] Fernández-Pérez MJ, Alarcón JA, McNamara JA Jr., et al. Spheno-occipital synchondrosis fusion correlates with cervical vertebrae maturation. PLoS ONE 2016; 11: e0161104.

[38] Ruf S, Pancherz H. Development of the frontal sinus in relation to somatic and skeletal maturity. A cephalometric roentgenographic study at puberty. Eur J Orthod. 1996; 18: 491-497.

[39] Buyuk SK, Simsek H, Karaman A. The relationship between frontal sinus morphology and skeletal maturation. Folia Morphol (Warsz). 2018 Jan 3. doi: 10.5603/FM.a2017.0118. [Epub ahead of print]

[40] Shim J, Heo G, Lagravère MO. Correlation between three-dimensional morphological changes of the hyoid bone with other skeletal maturation methods in adolescents. Oral Surg Oral Med Oral Pathol Oral Radiol. 2013; 116: 511-517.

[41] Melsen B. Palatal growth studied on human autopsy material. A histologic microradiographic study. Am J Orthod. 1975; 68: $42-54$.

[42] Gill D, Naini F, McNally M, et al. The management of transverse maxillary deficiency. Dent Update 2004; 31: 516-518, 521523.

[43] Perényi Á, Bella Z, Baráth Z, et al. Role of cone-beam computed tomography in diagnostic otorhinolaryngological imaging.
[A cone-beam komputertomográfia alkalmazása a fül-orr-gé gészeti képalkotásban.] Orv Hetil. 2016; 157: 52-58. [Hungarian]

[44] Jain N, Tripathi T, Gupta SK, et al. Serum IGF-1, IGFBP-3 and their ratio: potential biochemical growth maturity indicators. Prog Orthod. 2017; 18: 11.

[45] Ishaq RA, Soliman SA, Foda MY, et al. Insulin-like growth factor I: a biologic maturation indicator. Am J Orthod Dentofacial Orthop. 2012; 142: 654-661.

[46] Sinha M, Tripathi T, Rai P, et al. Serum and urine insulin-like growth factor- $\mathrm{l}$ as biochemical growth maturity indicators. Am J Orthod Dentofacial Orthop. 2016; 150: 1020-1027.

[47] Gupta S, Deoskar A, Gupta P, et al. Serum insulin-like growth factor-1 levels in females and males in different cervical vertebral maturation stages. Dental Press J Orthod. 2015; 20: 68-75.

[48] Tripathi T, Gupta P, Rai P, et al. Osteocalcin and serum insulinlike growth factor-1 as biochemical skeletal maturity indicators. Prog Orthod. 2017; 18: 30.

[49] Tripathi T, Gupta P, Sharma J, et al. Bone-specific alkaline phosphatase - a potential biomarker for skeletal growth assessment. J Orthod. 2017; 45: 4-10.

[50] Wen X, Franchi L, Chen F, et al. Proteomic analysis of gingival crevicular fluid for novel biomarkers of pubertal growth peak. Eur J Orthod. 2018; 40: 414-422. [Epub 28 October 2017]

(Frank Dorottya dr., Pécs, Dischka Gy. u. 5., 7621 e-mail: frank.dorottya@pte.hu)

\section{NOTA

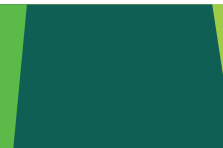 \\ Új fejlesztés az egészségügyben dolgozók, tanulók részére!}

A magyar nyelvứ szakirodalmi keresőszolgáltatás

\section{Mi a NOTA? \\ Napivizit Orvosi Tudástár Alkalmazás}

Mit tud a NOTA portál?

Megkönnyíti a magyar nyelvű szakirodalmi források keresését.

Eszköztöl függetlenül, aká okostelefonról, a betegágy mellett állva is használható.

\section{Miben kereshet a NOTA-val?}

Az Akadémiai Kiadó folyóirataiban: Orvosi Hetilap, Magyar Sebészet, Mentálhigiéné és Pszichoszomatika.

\section{Más kiadók magyar nyelvű} szakfolyóirataiban: pl. Lege Artis Medicinae, Hypertonia és Nephrologia, Ideggyógyászati Szemle.

A hatályos szakmai irányelvekben.

Magyar nyelvű kérdésekre adott ango nyelvű találatokban, a PubMeden.

\section{nota.hu}

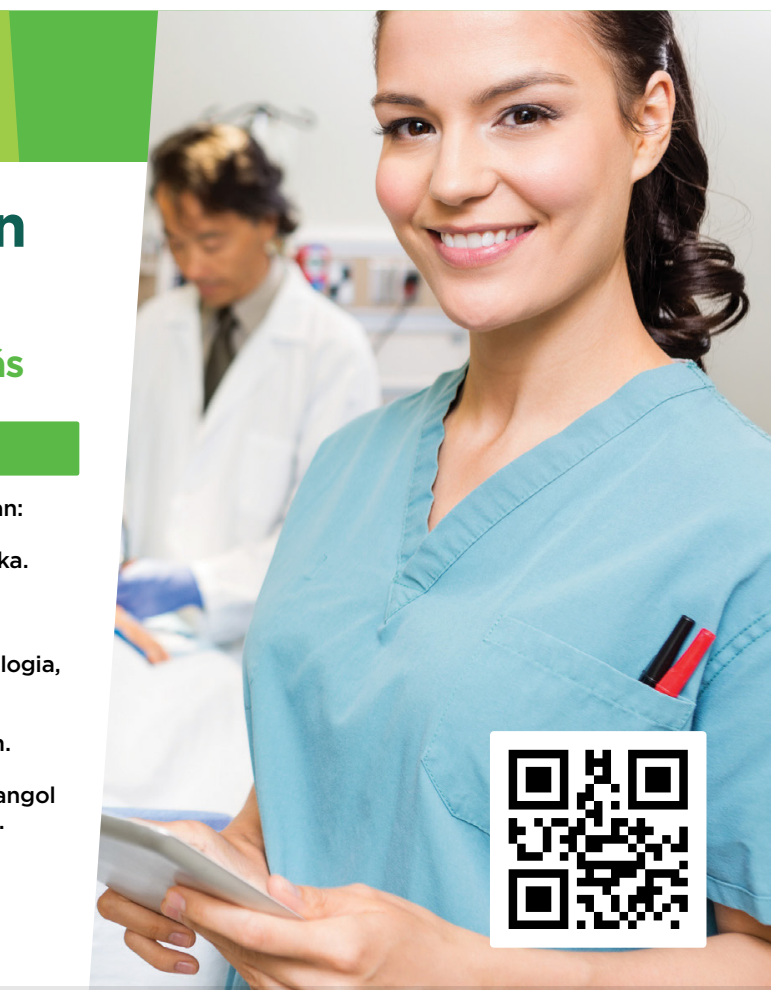

\section{Akadémiai Kiadó}

A Wolters Kluwer Csoport tagja

1117 Budapest, Prielle Kornélia u. 21-35. / Telefon: (1) 464-8246 www.akademiai.hu / www.akademiai.com

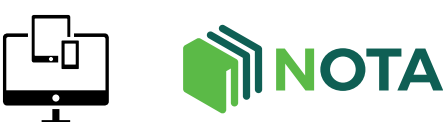

AKADÉMIAI KIADÓ 